\title{
Oil Palm Agroforestry Can Achieve Economic and Environmental Gains as Indicated by Multifunctional Land Equivalent Ratios
}

\author{
Nikmatul Khasanah ${ }^{1}$, Meine van Noordwijk ${ }^{1,2 \star}$, Maja Slingerland ${ }^{2}$, Mohammad Sofiyudin $^{1}$, \\ Dienke Stomph ${ }^{2}$, Adrien F. Migeon ${ }^{2}$ and Kurniatun Hairiah ${ }^{3}$ \\ ${ }^{1}$ Southeast Asia Regional Program, World Agroforestry (ICRAF), Bogor, Indonesia, ${ }^{2}$ Plant Production Systems, Wageningen \\ University and Research, Wageningen, Netherlands, ${ }^{3}$ Soil Science Department, Faculty of Agriculture, Brawijaya University, \\ Malang, Indonesia
}

Driven by increased global demand for vegetable oil in the food and biofuel sectors, oil palm plantations based on monoculture technology have expanded into lowland tropical forests. Interest in diversified, mixed oil palm systems is increasing as these

OPEN ACCESS

Edited by:

Agustin Del Prado,

Basque Centre for Climate

Change, Spain

Reviewed by:

Xavier Arnauld De Sartre

Centre National de la Recherche

Scientifique (CNRS), France

Johannes van Leeuwen,

National Institute of Amazonian

Research (INPA), Brazil

*Correspondence:

Meine van Noordwijk

m.vannoordwijk@cgiar.org

Specialty section:

This article was submitted to Agroecology and Ecosystem Services, a section of the journal

Frontiers in Sustainable Food Systems

Received: 17 June 2019 Accepted: 16 December 2019

Published: 21 January 2020

Citation:

Khasanah N, van Noordwijk M, Slingerland $M$, Sofiyudin $M$ Stomph D, Migeon AF and Hairiah $K$ (2020) Oil Palm Agroforestry Can Achieve Economic and Environmental Gains as Indicated by Multifunctional Land Equivalent Ratios.

Front. Sustain. Food Syst. 3:122.

doi: 10.3389/fsufs.2019.00122 might increase efficiency of the use of land and other resources, reduce farmer risk, and decrease greenhouse gas (GHG) emissions per unit product. Land Equivalent Ratio for provisioning services (LERP) values above 1.0 show that at least some diversified systems use land more efficiently than monocultures and are thus "land sparing," where monoculture LERP cannot exceed 1.0. Diversification also modifies climate and water regulating functions ("land sharing") relative to a forest reference, as indicated in the $\mathrm{LER}_{\mathrm{R}}$ index. A "multifunctional" $\mathrm{LER}_{\mathrm{M}}$ indicator combines both; land sparing plus land sharing effects jointly determine expected regulating services. Empirical assessment of multiple ecosystem services in agricultural landscapes is assisted by models that synthesise process-based knowledge, especially for perennial systems where welldesigned experiments require a full production cycle, and are costly and scarce. Agroforestry models explore spacing, intercropping and soil management options, predicting harvestable yields, impacts on water flows, nutrient leaching, and greenhouse gas emissions. We used the process-based Water, Nutrient and Light Capture in Agroforestry System (WaNuLCAS) model to explore mixed oil palm + cocoa and oil palm + pepper intercrop systems with modified ("double row") planting patterns for Indonesian contexts and estimated consequences for the carbon footprint. The oil palm + cocoa intercrop provided a high LERP (1.4), while also replenishing more ground water and having a lower $\mathrm{C}$ footprint. This combination also has a return to labour equal to that in oil palm monocultures and a higher benefit cost ratio than the oil palm + pepper combination that maximizes Net Present Value. Oil palm + cocoa systems are also less sensitive to price uncertainty for oil palm, and buffer for oil palm and cocoa production risks, assumed to be independent of each other. Considerable economic and environmental system improvements appear to be feasible through mixed oil palm systems and diversification as a pathway to intensification deserves full attention of research and policy development.

Keywords: carbon footprint, cocoa, ecosystem services, intercropping, land equivalent ratio (LER), oil palm, pepper, WaNuLCAS model 


\section{INTRODUCTION}

Oil palm production and the associated land use change has received worldwide attention, with many authors expecting that closing of yield gaps by intensified monoculture production will be best way to save land from further expansion. There is, however, an alternative view, grounded in the wider agroforestry literature. As part of the "land sparing" vs. "land sharing" debate (Renwick and Schellhorn, 2016; Mertz and Mertens, 2017; Phalan, 2018) the merits of intensified monoculture production (high yields, but also direct environmental impacts of high input use) have been compared with those of diversified, "ecologically intensified" production systems (lower yields, but better in terms of environmental services). As it refers to the amount of land needed to achieve the production of a range of products, the Land Equivalent Ratio (LER) is directly relevant for the "land sparing" debate (Martin-Guay et al., 2018). Interestingly, the common finding that LER values above 1 are feasible in intercropping (Szumigalski and van Acker, 2008; Yu et al., 2015), suggest that forms of "land sharing" may be the best way to achieve "land sparing" as a goal of efficient use of land. Khasanah et al. (2015a) found that LER values up to 1.8 are feasible for teak-maize systems in Central Java. As suggested recently (van Noordwijk et al., 2018), an extended $\mathrm{LER}_{M}$ index (with $\mathrm{m}=$ multifunctionality) can include further aspects of multifunctionality and ecosystem services beyond commodity production. This can be used to analyse landscape mosaics with monocultures as well as mixed cropping systems. As an example, we here focus on the potential rationales and methods for oil palm diversification in an agroforestry context, especially under smallholder management.

With around $40 \%$ of global agricultural lands having at least 10\% tree cover (Zomer et al., 2016; van Noordwijk et al., 2019a), agroforestry is far more common than its relative share in the published agricultural literature reflects. To contribute to increased coherence of currently segregated policies for agriculture and forestry, a more comprehensive set of methods and concepts to assess performance of agroforestry systems is needed (van Noordwijk and Coe, 2019). The combination of woody perennials and annual crops has consequences for the spatial and temporal scales at which interactions between provisioning ("production") and other ecosystem services should be evaluated in a life-cycle approach. Positive contributions can be expected especially for the required energy transformation (van Noordwijk et al., 2019b) and water management (van Noordwijk et al., 2019c), but the existing emission accounting systems and policy mix may contain perverse subsidies that need to be identified and corrected (Minang et al., 2019). Other functions, such as groundwater recharge, production/absorption of overland flows contributing to flooding through flow buffering, nitrogen filter functions, atmospheric methane production/consumption and carbon storage can also be expressed on an area basis and included in a modified multifunctionality $\mathrm{LER}_{\mathrm{M}}$ concept. As example of the utility of existing models, options for diversification of oil palm production will be discussed in terms of $L_{E R}$, as oil palm may well be the most controversial of current crops.
A tenfold increase in palm oil export from Indonesia in the period 2000-2020 has been forecasted (Directorate general of estate crops, 2016a), matching global demand for low-cost vegetable oil in food and biofuel sectors. Indonesia's oil palm expansion during the last two decades has resulted in widespread environmental and health damages through land clearing by fire and peat conversion, but it has also contributed to rural poverty alleviation (Naylor et al., 2019). The area planted with oil palm has increased to a current 12 Mha (6\% of Indonesia's land area). On much larger areas logging rights have been obtained for planned oil palm expansion. The deforestation observed and the associated greenhouse gas emissions and biodiversity loss have hence been attributed to "agriculture" as driver, rather than to transformations to fastwood plantations as part of "forest management" (Koh and Wilcove, 2008; Sheil et al., 2009; Koh et al., 2011; Carlson et al., 2012; van Noordwijk et al., 2017a). Yet, expansion of oil palm and the ease of obtaining the required permits have had major effects, replacing a very diverse natural vegetation, or still diverse rubber-based agroforestry (Joshi et al., 2003; Tata et al., 2008; Villamor et al., 2014) with a monoculture of oil palms, leaving only small riparian zones or local hills as "high conservation value areas." The multitude of "ecosystem services" of these diverse landscapes have been replaced by a singular focus on "provisioning" services for external markets (Tscharntke et al., 2012), providing income from which farmers or plantation labourers will have to buy what they in the past could obtain for free. "Outsourcing" of staple foods can be justified from a household economy perspective if the terms of trade are favourable, but micronutrient-rich food and dietary diversity are at risk if local food sources disappear (Naylor et al., 2007; Ickowitz et al., 2016). With farmgate prices fluctuating, specialization into a single commodity forms a considerable risk at household level, while companies can diversify at higher scales to buffer their risks. With smallholders increasing in their share of production, plot-level diversification deserves attention. External stakeholders focus on the environmental and social aspects of oil palm production (Padfield et al., 2019), but profitability considerations also matter for adoption by smallholders.

Expansion of oil palm has occurred mostly in lowland parts of Sumatra and Kalimantan where climate and soil are suitable, with average annual rainfall of at least $2,000 \mathrm{~mm}$, evenly distributed over the year without marked dry season, temperature in the $24-28^{\circ} \mathrm{C}$ range, $5-7 \mathrm{~h}$ of sunshine per day in all months, a slope $<5 \%$, well-drained soils that don't flood in wet periods, soils with clay, sandy clay or clay loam as texture, and no root restricting layers above $100 \mathrm{~cm}$ depth (Corley and Tinker, 2015). As the best sites (Northern part of Sumatra and Western part of Kalimantan), were converted first, current expansion (10\% years $^{-1}$ for the last 40 years; Directorate general of estate crops, 2016a), includes climates and soils beyond the optimal range, such as in the eastern part of Kalimantan, southern part of Sumatra and wettest parts of Sulawesi, affecting yield in various ways (Woittiez et al., 2017). In areas with longer dry periods increased soil water buffering is needed, but acid soil conditions restrict root development (Mutert, 1999) and make the palms more vulnerable to water stress, leading to increase in male and reduction of female inflorescences (Breure, 1982; Gawankar 
et al., 2003; Adam et al., 2011) depressing fruit production approximately 12 months after the stress occurs (Corley and Tinker, 2015; Woittiez et al., 2017). While oil palm was promoted in Malaysia in the 1960's as part of an agricultural diversification program (Simeh and Ahmad, 2001), it replaced rubber in large areas, rather than complementing it. Although intercropping oil palm and cocoa proved to be feasible (Amoah et al., 1995; Corley and Tinker, 2015), it required technical expertise and supply chain engagement beyond what companies were willing to invest in. For smallholders the pro and con of diversification may differ from those for companies. Diversification of oil palm plantations with cash crops may not only reduce the social and economic risks of depending on a single cash crop, it could even overcome some of the limiting factors for oil palm production in less suitable climate and soil conditions. Under some conditions the presence of other cash crops that have deeper root systems than oil palm (e.g., due to higher tolerance of acid subsoil conditions) could, through the hydraulic equilibration process (Bayala et al., 2008), maintain soil water content in the topsoil in dry periods, reducing the shift to male flowers in oil palm. Especially outside of the core oil palm area with the best soils and climates, mixed oil palm systems, as common in the African centre of origin of the species, might thus be a strategy for increasing net income, and income stability for farmers. Intercropping oil palm with food crops has been widely studied for several decades not only in its origin countries, but also in Asia. The studies addressed various research topics: local perceptions and strategies on intercropping, production of food crops at early stage of oil palm growth and residual effect of intercropping on the yield and productivity of oil palm at later production stage (Salako et al., 1995; Orewa, 2008; Putra et al., 2012; Okyere et al., 2014; Nchanji et al., 2016). Intercropping oil palm with cash crops received renewed attention recently (Slingerland et al., 2019). Gérard et al. (2017), Stomph (2017), and Migeon (2018) initiated studies on oil-palm yields in diversified plantations and reported that considerable economic and environmental system improvements appear to be feasible through mixed oil palm systems especially in sub-optimal climates where oil palm experiences some seasonal water stress.

In the context of palm oil used as biofuel feedstock, a diversification strategy might also have positive environmental impacts by reducing the carbon footprint and/or increasing $\mathrm{N}$ use efficiency through safety net functionality (Rowe et al., 1999; Suprayogo et al., 2002; Cadisch et al., 2004). Davis et al. (2013) introduced the term "management swing potential" for biofuel crops, comparing the best and worst ways of current production in terms of environmental impacts. There are some management options that might potentially "swing" the environmental impacts for palm oil as biofuel feedstock that link to aspects of the production systems (van Noordwijk et al., 2017b) for example strategic management options such as mixed tree species and associated planting patterns and tactical management options such as increased dose of fertilizer applications and use of methane trapping in oil processing.

This study aims to explore, analyse, and identify best performance of oil palm + cocoa and oil palm + pepper intercropping in the Indonesian context as a strategy to increase (or maintain) oil palm production in lower-risk and more land-efficient production systems. Exploration of feasibility of oil palm mixed systems can be tested directly in the field by establishing long-term experiments addressing strategic and tactical managements options to understand their trade-offs between productivity, economic and environmental performance. However, long-term experiments require a lot of time, labour, funds and persistence. Three-dimensional models of all above- and belowground interactions in resource capture are in development but are not yet easy to parameterize and use (Dupraz et al., 2019). Hence, this study relied on a well-established tree-soil-crop interaction model called Water, Nutrient and Light Capture in Agroforestry System (WaNuLCAS) (van Noordwijk and Lusiana, 1999; van Noordwijk et al., 2011) and the Biofuel Emission Reduction Estimator Scheme (BERES) (van Noordwijk et al., 2013). Specific routines were developed to describe growth and fruit production by palms and validated with existing production data from monoculture plantations. A crop library was made for pepper (Piper nigrum L.) by Migeon (2018) based on e.g., allometric relations and root development when grown in monocultures, while tree library for cacao already existed. The mixed systems were further analysed for the multifunctional land equivalent ratio $\left(\mathrm{LER}_{\mathrm{M}}\right.$ ), economic performance indicators (as in Khasanah et al., 2015a) and for environmental performance indicators. The current exploration is also informed by experimental plots that test sustainability of diversification of oil palm plantation in Brazil (cocoa) and Malaysia (pepper) (Khasanah, 2019).

Specific questions for the current study analysis were:

1. To what degree can mixed oil palm cocoa or pepper systems be a strategy to diversify oil palm production, reduce farmer risk and decrease GHG emissions?

2. To what degree can selected mixed oil palm systems be land saving strategies with a land equivalent ratio above 1 ?

3. How are various farm economic indicators (returns to land, labour, and investment) reflecting farmer risk and expected benefits in mixed systems compared to monoculture oil palm?

4. What effect will intercropping have on attributed carbon emissions per unit palm oil, in relation to the existing norms for biofuel emissions saving?

\section{METHODS}

\section{Study Area}

The exploration of intercropping oil palm using WaNuLCAS model is based on the climate and soil characteristics of an oil palm plantation of PT. Astra Agro Lestari in Kumai subdistrict (Pangkalan Bun district, Central Kalimantan, Indonesia; $2^{\circ}$ $25^{\prime} 17.68^{\prime \prime} \mathrm{S}, 111^{\circ} 46^{\prime} 52.8^{\prime \prime}$ E, $20 \mathrm{~m}$ asl). The explored site has minimum and maximum annual air temperatures of 23 and $32^{\circ} \mathrm{C}$, respectively; and an annual rainfall $2,200 \mathrm{~mm}$ years $^{-1}$ (Figure 1). The soil is an Ultisol with clay soil texture and with $\mathrm{pH}$ around 4 (Table 1). The soil data needed for the model were the result of laboratory analysis at Brawijaya University (Malang, Indonesia), except for bulk density; bulk density was estimated using a pedotransfer function (Wösten et al., 1995). 


\section{Model Use}

\section{Brief Description of WaNuLCAS Model}

The WaNuLCAS 4.3 model is a generic tree-crop growth model for a wide range of agroforestry systems that considers both above (light) and belowground (soil water and nutrient: $\mathrm{N}$ and $\mathrm{P}$ ) resources interaction as factors determining plant growth subject to complementarity and competition (van Noordwijk and Lusiana, 1999; van Noordwijk et al., 2011). The interactions are based on above- and below-ground architecture, physiology and phenology and interpreted in different modules including cropping management options (Figure 2A). As oil palm has different characteristics compared to other trees, a specific module was developed representing the physiology and phenology of oil palm flower and fruit development. The oil palm module includes five elements: time keeping of frond emergence (phyllochron time steps), sex determination of flowers, fruit abortion, bookkeeping of fruit stage development, and a possible harvest cycle of a fruit bunch at the end of each phyllochron. Three factors: water availability, nutrient availability, and growth reserves determine the dynamics of phyllochron time, flower determination, and fruit development.

The model represents a four-layer soil profile with four-spatial zone where trees and/or crops can be planted and has a daily time step (Figure 2B). The model was chosen for this study because it has flexibility to represent tree-crop management options. In this study the model was used to explore growth and production of oil palm, cocoa, and pepper when intercropped and to analyse

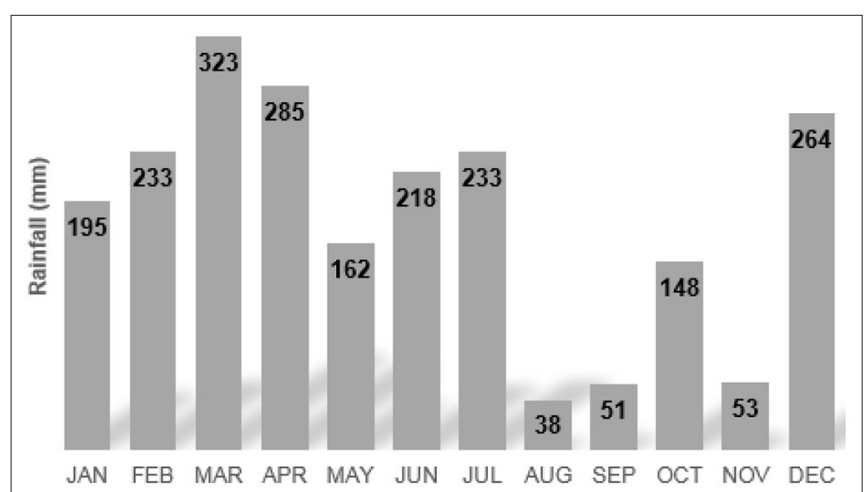

FIGURE 1 | Monthly rainfall for 2012, with annual total of 2,200 mm, used for model parameterization (source: PT. Agro Menara Rachmat). economic and environmental performance of each system using specific indicators and to assess its land productivity.

\section{WaNuLCAS Model Calibration and Validation}

Prior to the use of WaNuLCAS model to explore, analyse, and identify best performance of mixed oil palm systems, a series of model calibration and validation runs to test validity of the model were conducted on the monocultures. Extensive calibration and validation were conducted for oil palm growth and production. For cocoa and pepper growth and production parameterization and calibration have been conducted on smaller data sets by Stomph (2017) and Migeon (2018), respectively. Further fine tuning and evaluation consisted of comparisons of simulated data with average cocoa and pepper production as presented in tree crop estate statistics of Indonesia (Directorate general of estate crops, 2016b,c).

The main climate and soil data as presented in Figure 1 and Table 1 were used for model parameterization for all three crops. We repeated a single weather record for all years in the simulation to ease comparisons across intercropping systems, acknowledging that further studies with recorded interannual variation and multiple starting points therein could add further insights. We used tree and crop growth characteristic input parameters from the model libraries. For pepper Migeon (2018) parametrized the model based on field measurements of pepper monoculture in Konawe district, Southeast Sulawesi, Indonesia. We assumed a $3 \times 3 \mathrm{~m}$ spacing for the pepper in monoculture (Manohara and Wahyuno, 2013). Intercropping was based on $72 \%$ of oil palm $+29 \%$ of cocoa or pepper populations in monoculture. For fertilizer application, nitrogen $(\mathrm{N})$ and phosphorous (P) were applied to the systems with dose and schedule following Salim et al. (2009), Pahan (2015), and Manohara and Wahyuno (2013) for oil palm, cocoa and pepper, respectively (Table 2 ).

Evaluation of model performance was conducted by comparing simulated and measured data for oil palm monoculture. The oil palm data used for calibration and validation is average data of more than 20 plantation surveyed and published in Khasanah et al. $(2015 b, c)$ for aboveground and belowground carbon stocks during an oil palm lifecycle, respectively. Fertilizer applications can decrease or increase the net greenhouse emissions per unit palm oil, depending on the amounts used and the carbon debt incurred at conversion to oil palm (van Noordwijk et al., 2017b). For cocoa and pepper,

TABLE 1 | Soil characteristics of soil texture used for model parameterization.

\begin{tabular}{|c|c|c|c|c|c|c|c|c|c|}
\hline \multirow{2}{*}{$\begin{array}{l}\text { Layers } \\
(\mathrm{cm})\end{array}$} & Clay & Silt & Sand & Corg $_{\text {or }}$ & \multirow{2}{*}{$\begin{array}{l}\text { Bulk density } \\
\qquad\left(\mathrm{g} \mathrm{cm}^{-3}\right)\end{array}$} & \multirow{2}{*}{$\begin{array}{c}\text { CEC } \\
\left(\mathrm{cmol} \mathrm{kg}^{-1}\right)\end{array}$} & \multirow[t]{2}{*}{$\mathrm{pH}$} & \multirow{2}{*}{$\begin{array}{l}\mathrm{N} \text {-mineral } \\
\left(\mathrm{mg} \mathrm{cm}^{-3}\right)\end{array}$} & \multirow{2}{*}{$\begin{array}{l}\text { P-mineral } \\
\left(\mathrm{mg} \mathrm{kg}^{-1}\right)\end{array}$} \\
\hline & \multicolumn{4}{|c|}{ (\%) } & & & & & \\
\hline $0-10$ & 27.85 & 27.85 & 44 & 4.2 & 1.08 & 9.52 & 3.91 & 0.0041 & 9.66 \\
\hline 10-20 & 33.18 & 19.91 & 47 & 2.5 & 1.15 & 8.33 & 3.97 & 0.0038 & 4.57 \\
\hline $20-50$ & 47.54 & 13.72 & 39 & 1.2 & 1.28 & 7.95 & 3.99 & 0.0034 & 4.06 \\
\hline $50-100$ & 64.63 & 10.67 & 25 & 0.7 & 1.41 & 6.61 & 4.01 & 0.0012 & 0.89 \\
\hline
\end{tabular}

The data were the result of laboratory analysis, except for bulk density; bulk density was estimated using a pedotransfer function. 

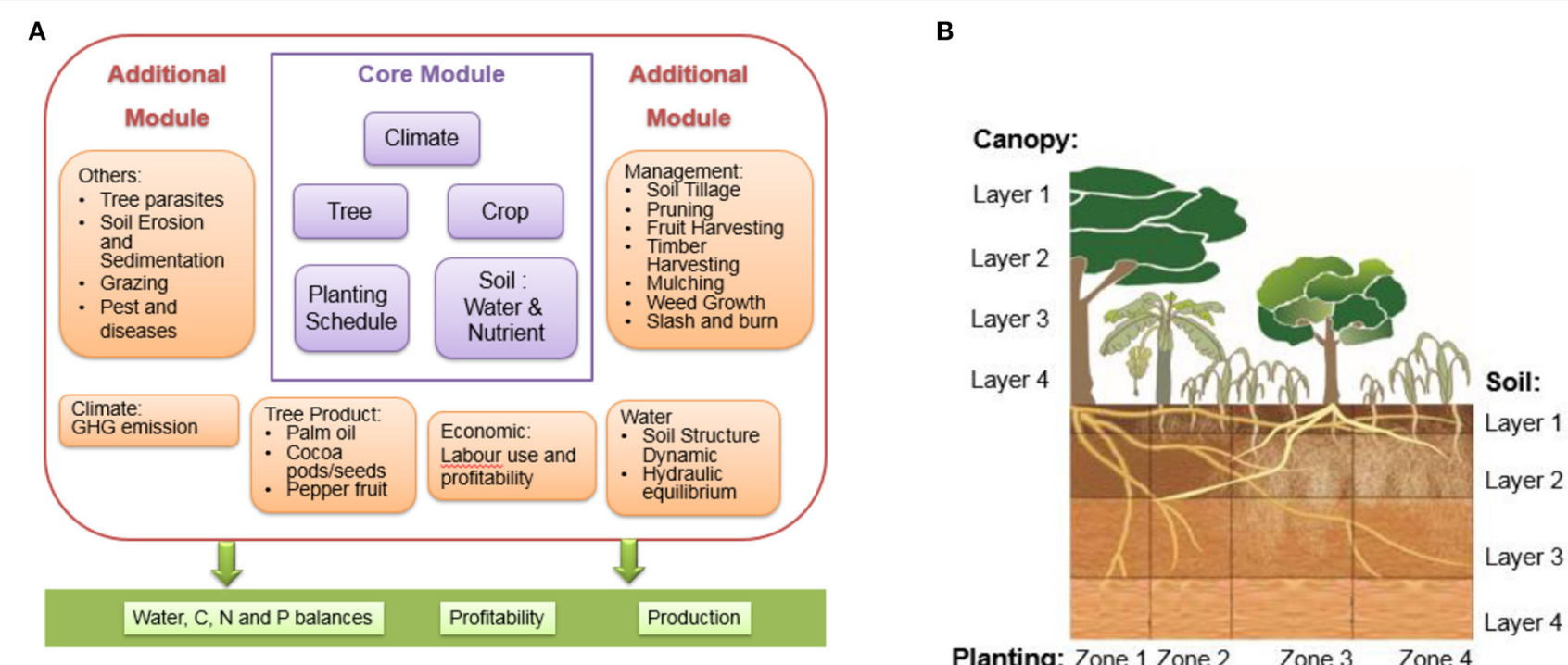

FIGURE 2 | Main modules in WaNuLCAS model that represent tree and crop in sharing light, water, and nutrient resources and its output (A), configuration of the models planting zones for trees and crops, canopy layers and soil layers (B).

TABLE 2 | Dose and schedule of fertilizer application following Pahan (2015) for oil palm, Salim et al. (2009) for cocoa, and Manohara and Wahyuno (2013) for pepper.

\begin{tabular}{|c|c|c|c|c|c|}
\hline \multirow[t]{2}{*}{ Schedule (Year) } & \multicolumn{2}{|c|}{ Oil palm (kg ha-1) } & \multicolumn{2}{|c|}{ Cocoa $\left(\mathrm{kg} \mathrm{ha}^{-1}\right)$} & \multirow{2}{*}{$\begin{array}{c}\text { Pepper }\left(\mathrm{kg} \mathrm{ha}^{-1}\right) \\
\text { NPK }\end{array}$} \\
\hline & Urea & TSP & $N$ & $P$ & \\
\hline 1 & 165.6 & 414 & 25.3 & 19.8 & 320 \\
\hline 2 & 213.9 & 207 & 41.4 & 32.4 & 640 \\
\hline 3 & 296.7 & 241.5 & 147.2 & 162.0 & 2,560 \\
\hline $4-5$ & 365.7 & 310.5 & 128.8 & 162.0 & 2,560 \\
\hline$>5$ years & 552 & 655.5 & 128.8 & 162.0 & 2,560 \\
\hline
\end{tabular}

simulated data was compared to national figures of cocoa and pepper production presented in the tree crop estate statistics for Indonesia) 2015-2017 (Directorate general of estate crops, 2016b,c). Statistical indicators proposed by Loague and Green (1991) (Table 3) and coefficient regression were used to evaluate the performance of the model for oil palm production.

\section{Representing Diversification Scenarios}

Mixed oil palm cocoa or pepper were selected as diversification scenarios. Details of planting density and years of intercropping are presented in Table 4, while Figure 3 presents design and spacing of intercropping oil palm with cocoa or pepper in a double row arrangement adapted from the system developed by Embrapa in Brazil and the Malaysian Oil Palm Board (Suboh et al., 2009), respectively. The selected scenarios considered different species characteristics, management requirements, profitability parameters, and environmental impacts. For environmental performance analysis, a long-term mixed natural forest was also simulated as reference for the same soil and climate conditions.

\section{Scenario Analysis Land Productivity}

The Land Equivalent Ratio (LER) indicates the relative area under monocropping needed to achieve the same functionality as an area intercropped. Functionality considerations can be grouped under provisioning services (or productivity of land), regulating services (e.g., with respect to water or nitrogen balance) and cultural services (e.g., landscape beauty). WaNuLCAS model outputs were used to calculate two components, $\mathrm{LER}_{\mathrm{P}}$ for provisioning and $\mathrm{LER}_{\mathrm{R}}$ for regulating services, of a multifunctional $\mathrm{LER}_{M}$ (van Noordwijk et al., 2018). For systems with only two components, as simulated here, the productivity $\mathrm{LER}_{\mathrm{P}}$ component was calculated as:

$$
\mathrm{LER}_{\mathrm{P}}=\mathrm{P}_{\mathrm{M}, 1} / \mathrm{P}_{\mathrm{S}, 1}+\mathrm{P}_{\mathrm{M}, 2} / \mathrm{P}_{\mathrm{S}, 2}
$$

Where $P_{M, 1}$ and $P_{M, 2}$ were the time-averaged yield of two components in mixed systems (intercropping), and $\mathrm{P}_{\mathrm{S}, 1}$ and $\mathrm{P}_{\mathrm{S}, 2}$ those in sole crops (monocultures), respectively. The equation can be readily expanded for more than two components.

\section{Environmental Performance Indicators}

WaNuLCAS model outputs were also used to calculate a number of regulating functions for mixed or sole crop systems, with simulations for forest conditions on the same soil and climate as reference. On this basis we calculated the LER for regulating services, $\mathrm{LER}_{\mathrm{R}}$ as:

$$
\mathrm{LER}_{\mathrm{R}}=\Sigma_{\mathrm{j}} \mathrm{w}_{\mathrm{j}}\left(\mathrm{R}_{\mathrm{j}, \mathrm{M}} / \mathrm{R}_{\mathrm{j}, \mathrm{F}}\right)^{\mathrm{sj}} / \Sigma_{\mathrm{j}} \mathrm{w}_{\mathrm{j}}
$$

With $\mathrm{R}_{\mathrm{j}, \mathrm{M}}$ and $\mathrm{R}_{\mathrm{j}, \mathrm{F}}$ the function ${ }_{j}$ (per unit area) in a mixed (or similarly for sole) system, and in forest conditions, respectively, $\mathrm{w}_{\mathrm{j}}$ a weighting factor and $\mathrm{s}_{\mathrm{j}}$ a sign $(+1$ for positive functions, -1 for disfunctions). 
TABLE 3 | Statistical criteria for model performance evaluation proposed by Loague and Green (1991) used for model performance evaluation.

\begin{tabular}{|c|c|c|c|c|c|}
\hline Criteria & Symbol & Calculation formula & Lower limit & Maximum & Optimum \\
\hline Maximum error & $\mathrm{ME}$ & $\operatorname{Max}\left|P_{i}-O_{i}\right|_{i=1}^{n}$ & 0 & & 0 \\
\hline Root mean square error & RMSE & $\left(\frac{\sum_{i=1}^{n}\left(P_{i}-O_{i}\right)^{2}}{n}\right)^{\frac{1}{2}} \times \frac{100}{O_{\text {mean }}}$ & 0 & & 0 \\
\hline Coefficient of determination & CD & $\frac{\sum_{i=1}^{n}\left(O_{i}-O_{\text {mean }}\right)^{2}}{\sum_{i=1}^{n}\left(P_{i}-O_{\text {mean }}\right)^{2}}$ & 0 & & 1 \\
\hline Modelling efficiency & $\mathrm{EF}$ & $\frac{\left(\sum_{i=1}^{n}\left(O_{i}-O_{\text {mean }}\right)^{2}-\sum_{i=1}^{n}\left(P_{i}-O_{i}\right)^{2}\right)}{\sum_{i=1}^{n}\left(O_{i}-O_{\text {mean }}\right)^{2}}$ & & 1 & 1 \\
\hline Coefficient of residual mass & CRM & $\frac{\left(\sum_{i=1}^{n} O_{i}-\sum_{i=1}^{n} P_{i}\right)}{\sum_{i=1}^{n} O_{1}}$ & & 1 & 0 \\
\hline
\end{tabular}

$P_{i}$, predicted values; $O_{i}$, observed values; $n$, number of samples; $O_{\text {mean; }}$ the mean of the observed data.

TABLE 4 | The simulated diversification scenarios with details on intercrop species, planting density, and years of intercropping.

\begin{tabular}{|c|c|c|c|c|c|}
\hline \multirow[t]{2}{*}{ Scenario } & \multirow[t]{2}{*}{ Systems } & \multirow[t]{2}{*}{ Intercropped species (IS) } & \multirow{2}{*}{$\frac{\text { Planting distance tree }(\mathrm{m})}{\text { Oil palm | IS }}$} & \multirow{2}{*}{$\frac{\text { Tree density (trees/ha) }}{\text { Oil palm | IS }}$} & \multirow[t]{2}{*}{ Years of crop } \\
\hline & & & & & \\
\hline 1. & Oil palm monoculture & - & $8.5 \times 8.5 \mid-$ & $138 \mid-$ & - \\
\hline 2. & Cocoa monoculture & - & $-13 \times 3$ & $-\mid 1,111$ & - \\
\hline 3. & Pepper monoculture & - & $-13 \times 3$ & $-\mid 1111$ & - \\
\hline 4. & Mixed oil palm & Cocoa & $7 \times 7.5 \times 19 \mid 4 \times 2.5 \times 22.5$ & $100 \mid 320$ & $-\mid 25$ \\
\hline 5. & Mixed oil palm & Pepper & $7 \times 7.5 \times 19 \mid 4 \times 2.5 \times 22.5$ & $100 \mid 320$ & $-\mid 25$ \\
\hline
\end{tabular}

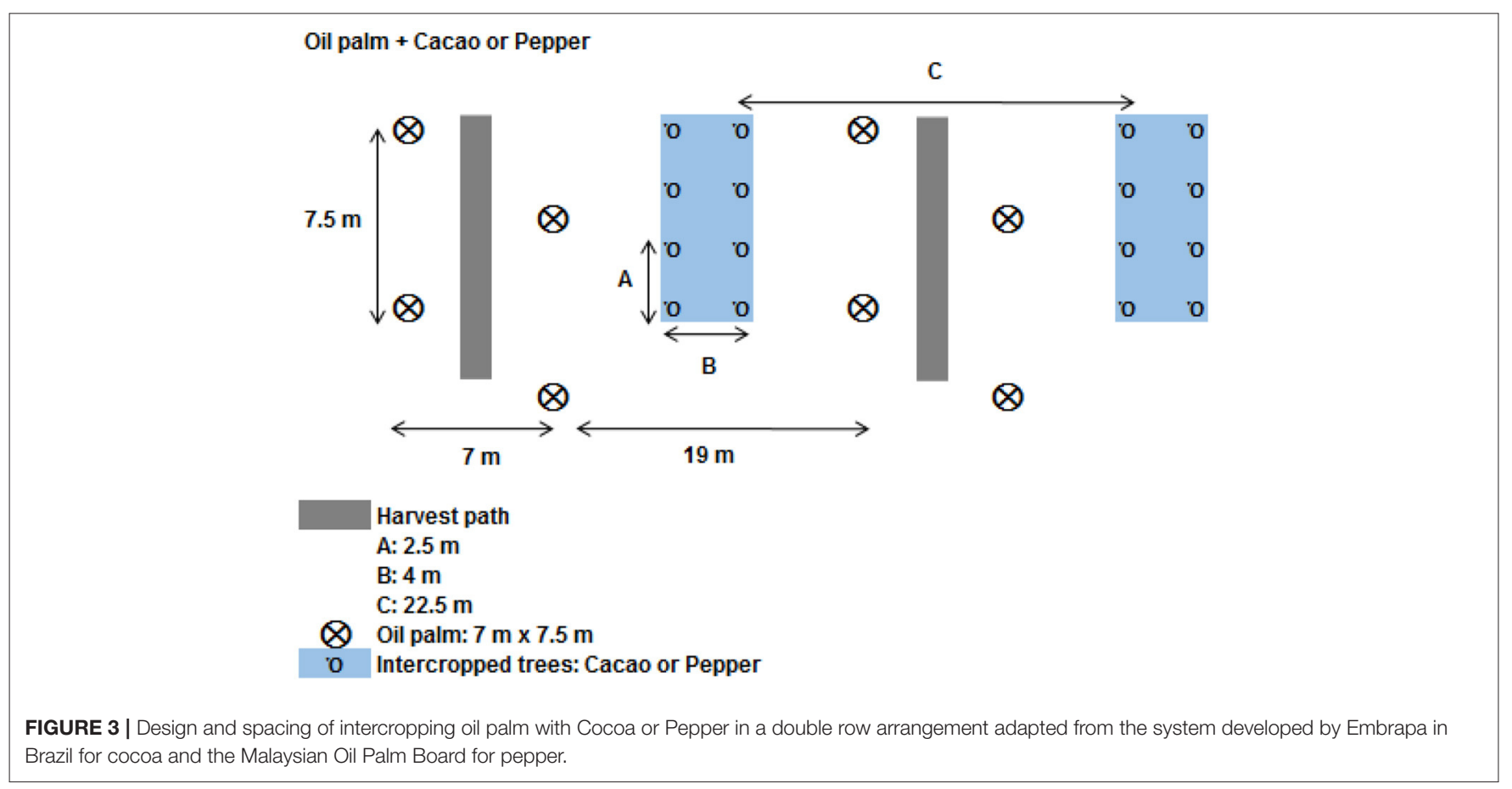

We used results for three functions: (1). Time-averaged C stock in $\mathrm{tC} \mathrm{ha}^{-1},(2)$. Water use (recycling to atmosphere) in mm $\mathrm{y}^{-1}$, (3). Groundwater recharge, $\mathrm{mm} \mathrm{y}^{-1}$ and two disfunctions, (4). Surface runoff in $\mathrm{mm} \mathrm{y}^{-1}$, and (5). $\mathrm{N}$ losses to ground- and surface water in $\mathrm{kg} \mathrm{N} \mathrm{ha}^{-1} \mathrm{y}^{-1}$.

Two versions are presented here, one with equal weights $\mathrm{w}_{\mathrm{j}}$ for the five indicators, and a second (more locally focused one) where C stock, water use efficiency, groundwater recharge, run off and $\mathrm{N}$ losses carried weights of $0.5,0.5,1.5,2$, and 1 , respectively.

$L_{E R}$ and $L E R_{R}$ were combined in a $L R_{M}$ indicator through a weighted sum:

$$
\operatorname{LER}_{M}=\left(w_{p, i} L^{2} R_{p}+w_{r, i} L_{L R}\right) /\left(w_{p, i}+w_{r, i}\right)
$$

with $\mathrm{w}_{\mathrm{p}, \mathrm{i}}$ and $\mathrm{w}_{\mathrm{r}, \mathrm{i}}$ the weights assigned by stakeholder $i$. 


\section{Land Sparing and Sharing Effects Combined}

Land sparing $\left(L_{E R}\right)$ and land sharing $\left(L_{E R}\right)$ effects can be combined for a net effect on regulating services that consists of a differential area of remaining forest:

$$
\mathrm{f}=\left(1-\mathrm{D} / \mathrm{LER}_{\mathrm{P}}\right)
$$

where $\mathrm{D}$ is the total demand relative to the area and its maximum sole-crop productivity, and a combined level of regulating services of:

$$
\mathrm{f}+(1-\mathrm{f}) \mathrm{LER}_{\mathrm{R} .}=1-\mathrm{D}\left(1-\mathrm{LER}_{\mathrm{R}}\right) / \mathrm{LER}_{\mathrm{P}} .
$$

The equation suggests that results depend on both sharing $\left(L_{E R}\right)$, as direct effect, and, if indeed there is a down-regulation of production area based on $\mathrm{D}$, by sparing $\left(\mathrm{LER}_{\mathrm{P}}\right)$.

\section{Economic Performance Indicators}

We used three economic performance indicators, Net Present Value (NPV) or Return to Land, Return to Labour (RtL), and benefit cost ratio (BCR). These indicators are used to determine whether the mixed system is profitable. When the NPV $>0$ and $\mathrm{RtL}$ is higher than the daily wage rate, it indicates that the mixed system is profitable. Returns to Labour is defined as the labour cost at which the NPV is zero. The NPV is calculated as follow:

$$
N P V=\sum_{t=0}^{t=n} \frac{R_{t}-C_{t}}{(1+i)^{t}}
$$

where: $R_{t}$ is revenue at year $t, C_{t}$ is cost at year $t$, and $i$ is discount rate.

A farm level assessment was developed for each system. Data were compiled on farm level inputs consisting of labour hours and costs, amounts and prices of fertilizer and other chemical inputs, planting materials and tools as required for the analysis, based on actual data collected in Sumatra (oil palm), Sulawesi (cocoa) and Kalimantan (pepper), the areas where the majority of the crops were produced. Prices of inputs were incorporated and estimated using local market prices, which included an interest rate of $7 \%$ and Rupiah currency exchange rate (USD $1=$ IDR 13.700). A labour wage rate was also included at USD 5 per day. Labour to cocoa processing from harvested pods to cocoa beans was included. Product prices were based on (Directorate general of estate crops, 2016a,b,c) for FFB (USD $0.1 / \mathrm{kg}$ ), cocoa (USD $1.7 / \mathrm{kg}$ ), and pepper (USD 10.2/kg).

\section{Carbon Footprint and Overall Performance}

WaNuLCAS model input (fertilizer application)—outputs (yield) were also used to estimate carbon footprint of palm oil for biofuel using Biofuel Emission Reduction Estimator Scheme (BERES) (van Noordwijk et al., 2013, 2017b) and compare it between scenarios to see which mixed system generates high yields while having a minimum carbon footprint at different amounts of carbon debt.

The BERES is a comprehensive accounting system on carbon dioxide $\left(\mathrm{CO}_{2}\right)$ and other greenhouse gas $(\mathrm{GHG})$ emissions of biofuel production of palm oil that includes three phase of crop production processes: land conversion, palm oil production and use of external inputs, and post-harvest transport and processing. It calculates carbon footprint or net emissions of biofuel production that is expressed as $\mathrm{CO}_{2}$ equivalent and emission saving compared to the use of fossil fuel using a life

TABLE 5 | Result of model performance evaluation according to Loague and Green (1991).

\begin{tabular}{lcccc}
\hline Criteria & Value & Lower limit & Maximum & Optimum \\
\hline ME & 8.6 & 0 & & 0 \\
RMSE & 18.5 & 0 & & 0 \\
CD & 0.6 & 0 & 1 & 1 \\
EF & -0.8 & & 1 & 1 \\
CRM & -0.1 & & & 0
\end{tabular}
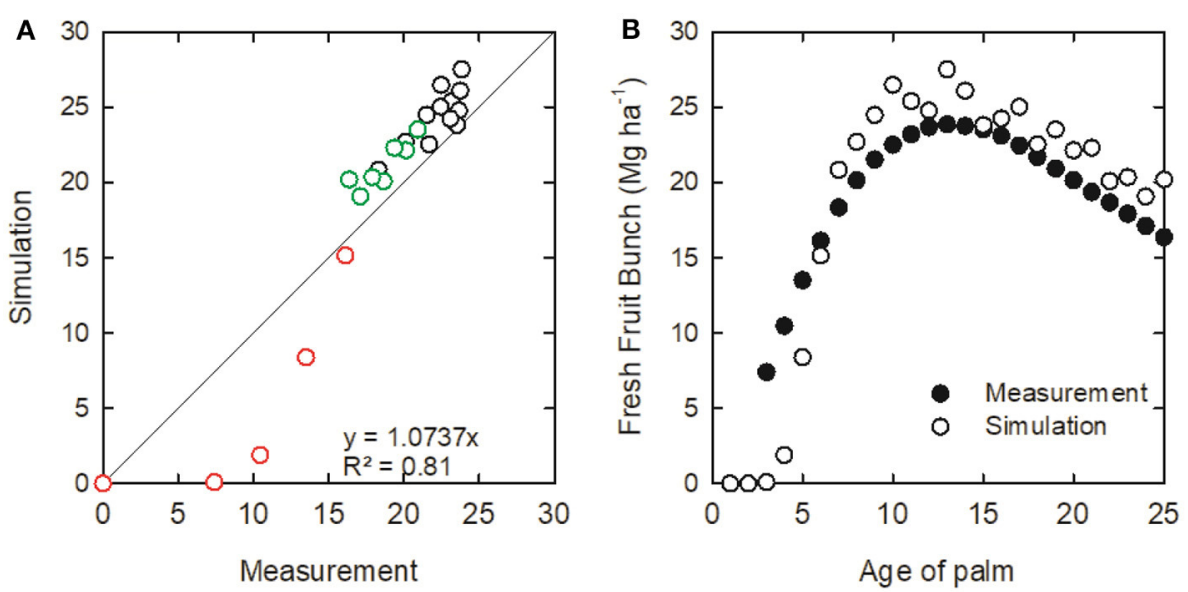

FIGURE 4 | A comparison of simulated and measured fresh fruit bunches of oil palm for a full production cycle (Mg ha-1), (A) direct, (B) as function of palm age. Red and green circle indicated for the early (measured higher than simulated) and late (simulated higher than measured) production stage, respectively. 

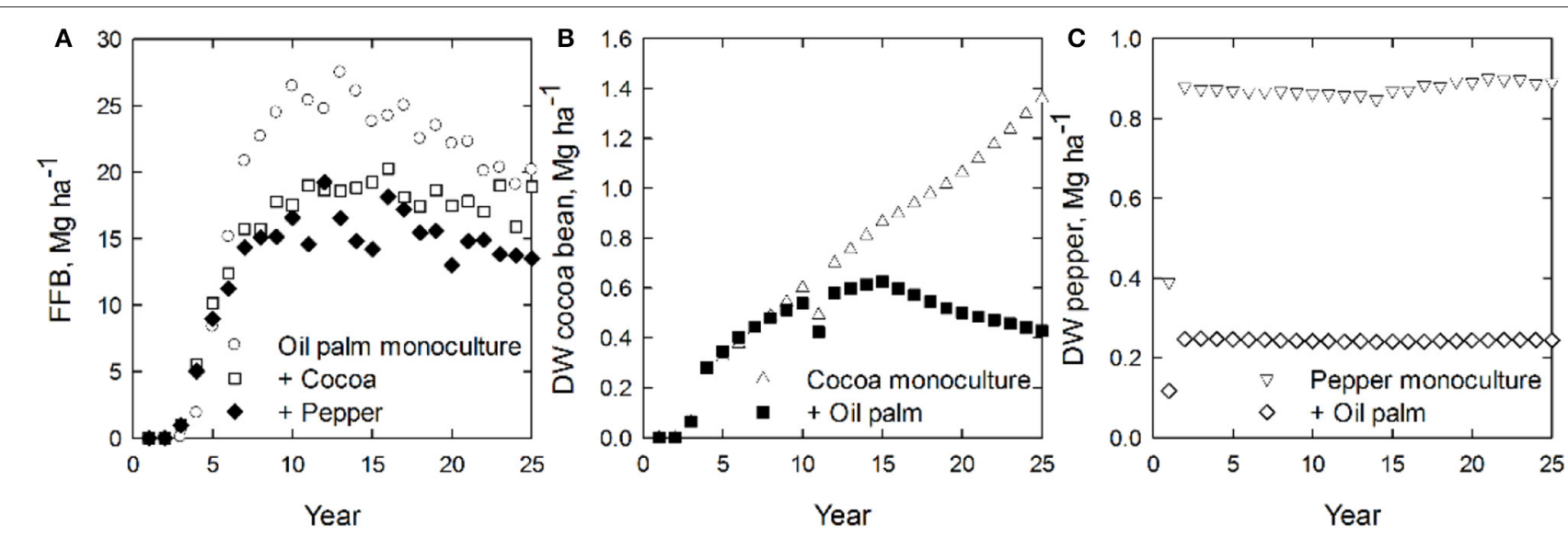

FIGURE 5 | Production of fresh fruit bunches (A), dry weight of cocoa bean (B), and dry weight of pepper (C) $\left(\mathrm{Mg} \mathrm{ha}^{-1}\right)$ of different simulated systems.

TABLE 6 | Land sparing as indicated by the provisioning services land equivalent ratio $(L E R P)$ and land sharing as indicated by five regulating services with reference to forest conditions for each simulated scenario.

\begin{tabular}{lcccccc}
\hline Systems & $\begin{array}{l}\text { Relative to } \\
\text { respective } \\
\text { monocultures }\end{array}$ & \multicolumn{5}{c}{ Relative to natural forest } \\
\hline LER $_{\mathbf{P}}^{\mathbf{a}}$ & $\begin{array}{c}\text { C } \\
\text { stock }\end{array}$ & $\begin{array}{c}\text { Water } \\
\text { use } \\
\text { efficiency }\end{array}$ & $\begin{array}{c}\text { Groundwater } \\
\text { recharge }\end{array}$ & & $\begin{array}{c}\text { Run } \\
\text { off }^{\mathbf{b}}\end{array}$ & $\begin{array}{c}\text { N } \\
\text { losses }^{\mathbf{b}}\end{array}$ \\
\hline $\begin{array}{l}\text { Monoculture } \\
\text { OP }\end{array}$ & 1.00 & 0.20 & 0.85 & 1.02 & 1.09 & 2.19 \\
OP + Cocoa & 1.44 & 0.15 & 0.69 & 1.13 & 1.17 & 2.59 \\
OP + Pepper & 0.99 & 0.13 & 0.87 & 0.87 & 1.02 & 3.89 \\
\hline
\end{tabular}

a Value above 1 means positive impact.

${ }^{b}$ Value above 1 means negative impact.

cycle approach. The scheme was used for this study to estimate one of environmental indicator as it is consistent with the life cycle analysis (LCA) of net emissions for biofuel production systems used by the renewable energy directive (RED) of the EU. We applied two scenarios of carbon footprint: with and without carbon debt sharing with intercropped trees.

\section{RESULTS}

\section{Model Performance Evaluation}

Figure 4 and Table 5 present comparison of simulated and measured fresh fruit bunch and evaluation of model performance of monoculture system. Overall evaluation of fresh fruit bunch indicated a moderately good fit between simulated and measured data with a coefficient determination and a coefficient regression of 0.6 (optimum value 1) and 1.07 (optimum value 1). The discrepancy is on the early (measured higher than simulated) and late (simulated higher than measured) production stage but both simulated and measured have average annual fresh fruit bunch yields over one cycle (of 25 years) of around $19.5 \mathrm{Mg} \mathrm{ha}^{-1}$. Cocoa and pepper monoculture systems have average annual production over one cycle (of equal length to oil palm) of around
775 and $856 \mathrm{~kg} \mathrm{ha}^{-1}$, respectively. This value is close to the figure of cocoa and pepper production described in tree crop estate statistics of Indonesia (Directorate general of estate crops, 2016b,c).

\section{Production}

Figure 5 describes production of fresh fruit bunch (Figure 5A), dry weight of cocoa bean (Figure 5B) and dry weight of pepper (Figure 5C) $\left(\mathrm{Mg} \mathrm{ha}^{-1}\right)$ of different simulated systems. The yield of oil palm responds to the changes of design (from single row to double row), tree density (from 138 to 100 palms ha $^{-1}$ ), and intercropped tree (cocoa and pepper). Under single row arrangement and with a density of 138 palms $\mathrm{ha}^{-1}$, average fresh fruit bunch over one cycle was around $19.5 \mathrm{Mg} \mathrm{ha}^{-1}$; it decreased to 16 and $14 \mathrm{Mg} \mathrm{ha}^{-1}$ when intercropped with cocoa and pepper in double row arrangement, respectively. Yields of cocoa and pepper under monoculture systems were around 775 and $856 \mathrm{~kg} \mathrm{ha}^{-1}$ for cocoa and pepper, respectively. Due to different shade tolerance of the two crops, yields reduced to $475 \mathrm{~kg} \mathrm{ha}^{-1}$ (cocoa) and $240 \mathrm{~kg} \mathrm{ha}^{-1}$ (pepper) when intercropped with oil palm, with a relative tree density of $29 \%$ for both crops.

\section{Land Productivity and Environmental Performances Indicators}

Table 6 presents land productivity indicated by land equivalent ratio $\left(\mathrm{LER}_{\mathrm{P}}\right)$ value and $\mathrm{LER}_{\mathrm{R}}$ components relative to a forest reference condition. The $L_{E R}$ of oil palm + cocoa intercrop exceeds 1 (1.4), while the $\operatorname{LER}_{P}$ of oil palm + pepper intercrop is 1.0. However, in term of environmental performance indicators (LER $\mathrm{R}_{\mathrm{R}}$ components), oil palm monoculture has higher $\mathrm{C}$ stock and water use, and lower run off and $\mathrm{N}$ losses than the cocoaoil palm intercrop. The cocoa + oil palm intercrop has a higher groundwater recharge compared to oil palm monoculture. If we compare the $\mathrm{LER}_{\mathrm{R}}$ components of oil palm + cacao intercrop and oil palm + pepper intercrop, both have considerable advantages over the oil palm monoculture. Furthermore, oil palm monoculture and oil palm + cocoa intercrop had 
TABLE 7 | Economic performance indicators Net Present Value (NPV), return to labour (RtL), Benefit Cost Ratio (BCR), years to positive cash flow and cost of establishment, for each simulated scenario with added uncertainty in physical yield (from 0.8 to 1.2 times the default value for oil palm, cocoa or pepper) and Fresh Fruit Bunch (FFB) prices (from 0.1 to $0.07 \mathrm{USD} \mathrm{kg}^{-1}$ ).

\begin{tabular}{|c|c|c|c|c|c|c|c|c|c|c|c|c|c|c|c|c|}
\hline \multirow[t]{2}{*}{ Systems } & \multirow[t]{2}{*}{$\begin{array}{l}\text { Price of } \\
\text { FFB, } \\
\text { USD/kg }\end{array}$} & \multicolumn{3}{|c|}{$\begin{array}{l}\text { NPV (USD ha-1, } \\
\text { relative to default) }\end{array}$} & \multicolumn{3}{|c|}{$\begin{array}{l}\text { RtL (USD Person } \\
\text { day }^{-1} \text {, relative to } \\
\text { default) }\end{array}$} & \multicolumn{3}{|c|}{$\begin{array}{c}\text { BCR (ratio, relative to } \\
\text { default) }\end{array}$} & \multicolumn{3}{|c|}{$\begin{array}{c}\text { Years to positive cash } \\
\text { flow (\#years, relative } \\
\text { to default) }\end{array}$} & \multicolumn{3}{|c|}{$\begin{array}{c}\text { Establishment cost } \\
\text { (USD ha }{ }^{-1} \text {, relative to } \\
\text { default) }\end{array}$} \\
\hline & & $0.8 \mathrm{Y}$ & $\mathbf{Y}$ & $1.2 \mathrm{Y}$ & $0.8 \mathrm{Y}$ & $\mathbf{Y}$ & $1.2 \mathrm{Y}$ & $0.8 \mathrm{Y}$ & $\mathbf{Y}$ & $1.2 \mathrm{Y}$ & $0.8 \mathrm{Y}$ & $\mathbf{Y}$ & $1.2 \mathrm{Y}$ & $0.8 \mathrm{Y}$ & $\mathbf{Y}$ & $1.2 \mathrm{Y}$ \\
\hline \multicolumn{17}{|c|}{ Y VARIATION IN OIL PALM } \\
\hline \multirow{4}{*}{$\begin{array}{l}\text { Oil palm } \\
\text { monoculture }\end{array}$} & 0.1 & 7,988 & 11,062 & 14,137 & 23.7 & 30.9 & 38.1 & 2.2 & 2.5 & 2.8 & 5 & 5 & 5 & 1838 & 1910 & 1981 \\
\hline & & 0.72 & 1.00 & 1.28 & 0.77 & 1.00 & 1.23 & 0.88 & 1.00 & 1.12 & 1.00 & 1.00 & 1.00 & 0.96 & 1.00 & 1.04 \\
\hline & 0.07 & 3,776 & 5,797 & 7,818 & 13.9 & 18.6 & 23.3 & 1.6 & 1.8 & 2 & 5 & 5 & 5 & 1839 & 1910 & 1981 \\
\hline & & 0.34 & 0.52 & 0.71 & 0.45 & 0.60 & 0.75 & 0.64 & 0.72 & 0.80 & 1.00 & 1.00 & 1.00 & 0.96 & 1.00 & 1.04 \\
\hline \multirow[t]{4}{*}{ Oil palm + Cocoa } & 0.1 & 12,167 & 14,656 & 17,144 & 26.1 & 30.4 & 34.7 & 2.9 & 3.1 & 3.3 & 4 & 4 & 4 & 1291 & 1317 & 1344 \\
\hline & & 1.10 & 1.32 & 1.55 & 0.84 & 0.98 & 1.12 & 1.16 & 1.24 & 1.32 & 0.80 & 0.80 & 0.80 & 0.68 & 0.69 & 0.70 \\
\hline & 0.07 & 8,816 & 10,467 & 12,118 & 20.3 & 23.2 & 26.0 & 2.4 & 2.5 & 2.6 & 4 & 4 & 4 & 1291 & 1317 & 1344 \\
\hline & & 0.80 & 0.95 & 1.10 & 0.66 & 0.75 & 0.84 & 0.96 & 1.00 & 1.04 & 0.80 & 0.80 & 0.80 & 0.68 & 0.69 & 0.70 \\
\hline \multirow[t]{4}{*}{ Oil palm + Pepper } & 0.1 & 19,129 & 21,603 & 23,348 & 12.1 & 12.9 & 13.6 & 2.0 & 2.1 & 2.2 & 2 & 2 & 2 & 1206 & 1206 & 1206 \\
\hline & & 1.73 & 1.95 & 2.11 & 0.39 & 0.42 & 0.44 & 0.80 & 0.84 & 0.88 & 0.40 & 0.40 & 0.40 & 0.63 & 0.63 & 0.63 \\
\hline & 0.07 & 16,212 & 17,592 & 18,972 & 11.0 & 11.5 & 12.0 & 1.9 & 1.9 & 2.0 & 2 & 2 & 2 & 1206 & 1206 & 1206 \\
\hline & & 1.47 & 1.59 & 1.72 & 0.36 & 0.37 & 0.39 & 0.76 & 0.76 & 0.80 & 0.40 & 0.40 & 0.40 & 0.63 & 0.63 & 0.63 \\
\hline \multicolumn{17}{|c|}{ Y VARIATION IN COCOA } \\
\hline \multirow[t]{4}{*}{ Oil palm + Cocoa } & 0.1 & 13,353 & 14,656 & 15,958 & 29.5 & 30.4 & 31.2 & 3 & 3.1 & 3.2 & 4 & 4 & 4 & 1306 & 1317 & 1329 \\
\hline & & 1.21 & 1.32 & 1.44 & 0.95 & 0.98 & 1.01 & 1.20 & 1.24 & 1.28 & 0.80 & 0.80 & 0.80 & 0.68 & 0.69 & 0.70 \\
\hline & 0.07 & 9,164 & 10,467 & 11,769 & 21.8 & 23.2 & 24.4 & 2.4 & 2.5 & 2.6 & 4 & 4 & 4 & 1306 & 1317 & 1329 \\
\hline & & 0.83 & 0.95 & 1.06 & 0.71 & 0.75 & 0.79 & 0.96 & 1.00 & 1.04 & 0.80 & 0.80 & 0.80 & 0.68 & 0.69 & 0.70 \\
\hline \multicolumn{17}{|c|}{ Y VARIATION IN PEPPER } \\
\hline \multirow[t]{4}{*}{ Oil palm + Pepper } & 0.1 & 18,110 & 21,603 & 24,367 & 13.1 & 12.9 & 12.7 & 2.1 & 2.1 & 2.1 & 2 & 2 & 2 & 1101 & 1206 & 1310 \\
\hline & & 1.64 & 1.95 & 2.20 & 0.42 & 0.42 & 0.41 & 0.84 & 0.84 & 0.84 & 0.40 & 0.40 & 0.40 & 0.58 & 0.63 & 0.69 \\
\hline & 0.07 & 14,463 & 17,592 & 20,721 & 11.5 & 11.5 & 11.5 & 1.9 & 1.9 & 2.0 & 2 & 2 & 2 & 1101 & 1206 & 1310 \\
\hline & & 1.31 & 1.59 & 1.87 & 0.37 & 0.37 & 0.37 & 0.76 & 0.76 & 0.80 & 0.40 & 0.40 & 0.40 & 0.58 & 0.63 & 0.69 \\
\hline \multicolumn{17}{|l|}{ RELATIVE RANGES } \\
\hline \multicolumn{2}{|l|}{ Oil palm monoculture } & \multicolumn{3}{|c|}{$0.34-1.28$} & \multicolumn{3}{|c|}{$0.45-1.23$} & \multicolumn{3}{|c|}{$0.64-1.12$} & \multicolumn{3}{|c|}{1.0} & \multicolumn{3}{|c|}{$0.96-1.04$} \\
\hline \multicolumn{2}{|l|}{ Oil palm + Cocoa } & \multicolumn{3}{|c|}{$0.80-1.55$} & \multicolumn{3}{|c|}{$0.66-1.12$} & \multicolumn{3}{|c|}{$0.96-1.32$} & & 0.8 & & & $68-0$ & \\
\hline Oil palm + Pepper & & & $1.31-2.20$ & & & $0.37-0.4$ & & & $0.76-0.88$ & & & 0.4 & & & $58-0$ & \\
\hline
\end{tabular}

Y, year.

greater groundwater recharge than the forest, as our model parameters suggested soil conditions to be conducive to deep drainage.

\section{Economic Performance Indicators}

Table 7 presents economic performance indicators represented by NPV, return to labour, Benefit Cost Ratio (BCR), years to positive cash flow and cost of establishment. Compared to monoculture, and discounting costs and benefits over a 25 years of cycle, oil palm + cocoa, and oil palm + pepper provide a 24 and $48 \%$ higher NPV, respectively. However, to establish and maintain the intercrops an additional labour input of 7\% (oil palm + cocoa) and $72 \%$ (oil palm + pepper) was required. This is reflected in the reduction of RtL by $3 \%$ for oil palm + cocoa and $141 \%$ for oil palm + pepper. Oil palm + cocoa had the highest BCR. Further analysis at reduced FFB price and assumed uncertainty of yield of both oil palm and intercropped trees, showed further advantages of the oil palm + cocoa scenario for all economic indicators. The establishment cost is sum of cost before reaching positive cash flow, hence it varies between yield.

\section{Carbon Footprint}

Figure 6 presents the carbon footprint of palm oil when it is used as biofuel and is produced in various land use systems, with various amount of $\mathrm{C}$ debt due to initial conversion. The carbon footprint is presented as emissions saving (\%) compared to the use of fossil fuel. Without sharing of the load of carbon debt with intercropped trees and with current target of emission saving $(60 \%)$, oil palm + cocoa intercrop can meet the target at maximum $10 \mathrm{Mg} \mathrm{C} \mathrm{ha}{ }^{-1}$ carbon debt, the same situation also provided by oil palm monoculture (Figure 6A). The saving can be higher if we apply sharing of the load of the carbon debt with intercropped trees (Figure 6B), but the debt cannot be higher than $10 \mathrm{Mg} \mathrm{ha}^{-1}$ if one has to meet the target. 


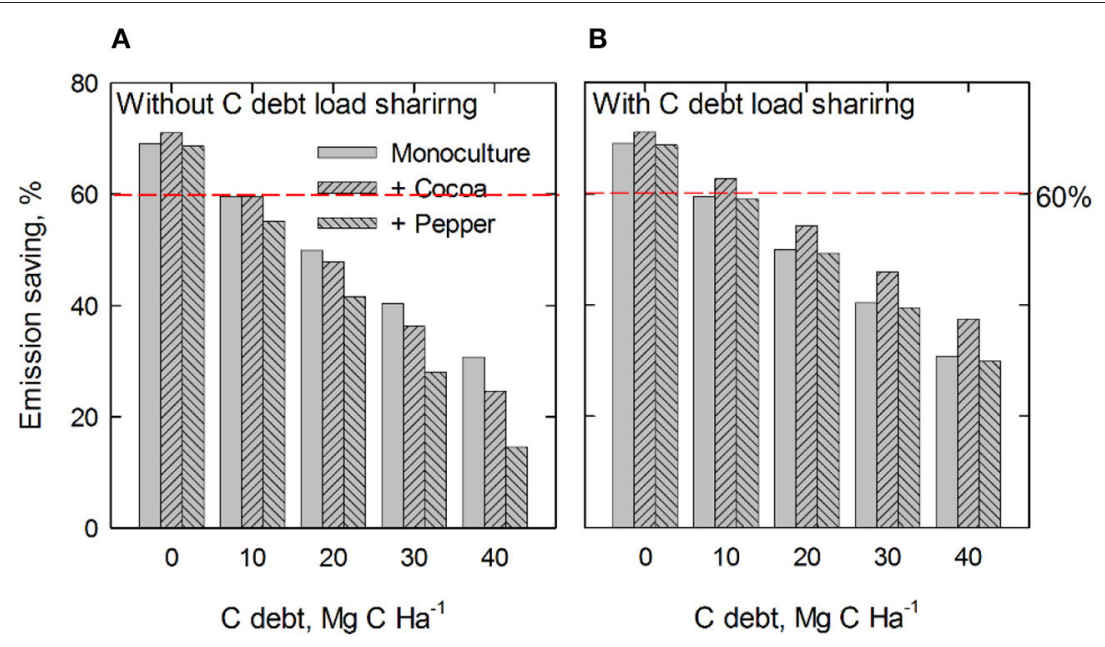

FIGURE 6 | Carbon footprint of palm oil when it is used as biofuel under different systems and various amount of $\mathrm{C}$ debt, without (A), and with (B) sharing of the $\mathrm{C}$ debts over the intercropped trees. The carbon footprint is presented as saving emission (\%) compared to the use of fossil fuel.

\section{DISCUSSION}

This study aims to explore, analyse, and identify best performance of oil palm + cocoa and oil palm + pepper intercrop within the Indonesian context on mineral soils as a strategy to increase oil palm production and reduce the carbon footprint and hypothesized that selected mixed oil palm systems have land sparing with a land equivalent ratio above 1, improve farmer benefits and reduce carbon emissions. The results showed that mixed oil palm achieved the targets. On peat soils subsidence and carbon emissions are so high in smallholder systems that intercropping won't help to reduce emissions (Khasanah and van Noordwijk, 2018).

The land equivalent ratio $\left(\mathrm{LER}_{\mathrm{P}}\right)$ of oil palm + cocoa intercrop exceeds 1 (1.44), while for oil palm + pepper it is 0.99 . It indicated that there is indeed a benefit in term of production to be obtained by combining oil palm and cocoa compared to their monocultures. Although mixed oil palm required additional labour compared to oil palm monoculture as indicated in lower return to labour, under smallholder management this might not a limitation (Vermeulen and Goad, 2006; Schwarze et al., 2015). The economic performance of oil palm + cocoa intercrop is also more resistant to the uncertainty of price of oil palm and variation in production of oil palm and cocoa. In hindsight the planting density chosen for the oil palm + pepper intercrop may have been lower than optimal and the simulations may not indicate the full potential of this type of intercropping. As applies to all parameters selected, further optimization could indeed shift our results which, at this stage may represent a conservative underestimate of the $\mathrm{LER}_{\mathrm{p}}$ values achievable. From an environmental perspective, both oil palm + pepper intercrop and oil palm + cocoa intercrop has certain environmental performance benefits: Runoff decreased and atmospheric moisture recycling (water use) increased under oil palm + pepper intercrop, whereas ground water recharge increased under oil palm + cocoa intercrop. However, C stock decreased, and $\mathrm{N}$ losses increased under both intercrops compared to oil palm monoculture. Zooming in into the carbon footprint, which is relevant when the palm oil is used for biofuel, palm oil from oil palm + cocoa intercropping, with maximum carbon debt of $10 \mathrm{Mg} \mathrm{C} \mathrm{ha}{ }^{-1}$ complies to the threshold of $60 \%$ savings compared to fossil fuel as set by the European Union. However, to achieve this, smallholders need to follow best management practices which would be an enormous challenge for especially the independent smallholders. Independent smallholders have the most complex cropping systems, and are the most diverse in their management practices, and are often not connected to input suppliers and markets hence the cost to comply to certification for the biofuel market might not be economically feasible (Hutabarat et al., 2018).

The presented examples illustrate the complexity of decision making and defining a farming practice as the most sustainable option from economic and environmental perspectives. For example, if a smallholder seeks an early positive net return, high WUE and low run-off, oil palm + pepper is preferred, if a smallholder aims at obtaining higher returns to labour, low establishment cost and enhanced environmental performance in terms of a lower carbon footprint oil palm + cocoa is preferred. When the farmer is only focused on returns to labour, the oil palm monoculture can be chosen.

Multifunctionality perspectives must reconcile trade-offs that exist between various aspects of environmental and economic performance. The LER , or productivity focussed land equivalent ratio, is interpreted here as indicator of "land sparing": a higher ratio implies that less land is needed to obtain the same amount of commodities (assuming that there is demand for oil palm, cocoa and pepper, and that they can be produced in either mixed systems or monocultures). The $\mathrm{LER}_{\mathrm{P}}$ reflects opportunity for biodiversity and $\mathrm{C}$ stock conservation outside of the productive parts of the landscape. The $\mathrm{LER}_{\mathrm{R}}$, or land equivalent ratio for regulating functions, involves five indicators (Table 6): the globally relevant $\mathrm{C}$ stock, water use efficiency, groundwater recharge, surface runoff and $\mathrm{N}$ losses, all scaled by the values that can be expected for forest in the same soil and climate. The latter two are treated as disfunctions, and the inverse of the relative value is added for a $L_{E R}$. Stakeholders may attach different 
TABLE 8 | Multifunctional land equivalent ratio $L E R_{M}$ on the basis of land sparing indicator LERP and land sharing indicator $L_{E} R_{R}$ (for provisioning and regulating functions, respectively) for three different land use systems.

\begin{tabular}{lccccc}
\hline Systems & LER $_{\mathbf{P}}$ & LER $_{\mathbf{R} 1}^{\mathbf{a}}$ & LER $_{\mathbf{R} 2}^{\mathbf{b}}$ & LER $_{\text {M1 }}^{\mathbf{c}}$ & LER $_{\text {M2 }}^{\mathbf{d}}$ \\
\hline Monoculture oil palm (OP) & 1.00 & 0.69 & 0.79 & 0.84 & 0.90 \\
Oil palm + cocoa & 1.44 & 0.64 & 0.77 & 1.04 & 1.10 \\
Oil palm + pepper & 0.99 & 0.62 & 0.73 & 0.81 & 0.86 \\
\hline
\end{tabular}

a Equal weight for $C$ stock, atmospheric moisture recharge, groundwater recharge, run off and $\mathrm{N}$ losses (1), data in Table 6.

${ }^{b}$ Weight for $C$ stock, atmospheric moisture recharge, groundwater recharge, run off, and $N$ losses is $0.5,0.5,1.5,2$, and 1 , respectively.

${ }^{c}$ Combining $L E R_{P}$ and $L E R_{R 1}$ at equal weight.

${ }^{d}$ Combining $L E R_{P}$ and $L E R_{R 2}$ at equal weight.

levels of importance to these functions. We here considered an equal weighting for the five indicators, and a more locally focussed one where groundwater recharge is valued most and C stock least. Results (Table 8) show that for the functions considered the $\mathrm{LER}_{\mathrm{R}}$ of oil palm monoculture is (slightly) higher than that for the intercropping systems, but all values are clearly below 1.0 (which uses the natural forest as reference). When comparing the $L_{E R}$ values (so far with equal weights for $L_{E R}$ and LER $_{R}$ ), the oil palm + cocoa system is the highest (and only above 1 ), for both ways of weighing regulating functions.

The "land sparing" literature (Phalan, 2018) assumes a downregulation of production area based on demand $\mathrm{D}$. If we can assume the "land sparing" effect of an increase in forest area when land is more productive to be fully realized, and the $L_{R}$ values are substituted in equation [5], the net effect on regulating services will be $1-0.31 \mathrm{D}, 1-0.25 \mathrm{D}$, and $1-0.38 \mathrm{D}$ for oil palm monoculture, oil palm + cocoa and oil palm + pepper, respectively. The, oil palm + cocoa system thus implies the lowest loss of regulating services relative to forest.

The intercropping scenarios we tested were largely based on replacement of part of the oil palm population by other crops, rather than aiming for additional canopy layers within stands of normal oil palm density. It may be that scenarios with higher total plant density might perform even better than what our model results showed so far, but they would also involve higher costs for planting material and need to be critically evaluated in a bioeconomic sense.

Economic performance indicators presented in Table 7 are combined with the environmental performance indicators presented in Table 8 for an overall evaluation of the trade-offs between negative environmental impacts and positive increase of welfare. All three systems considered have Benefit Cost Ratios substantially above 1.0 , so they are "bankable" at commercial interest rates. When Net Present Value (returns to land) is to be maximized (while paying for labour at the going wage rate), the combination of oil palm and pepper is best; it also has the shortest time to positive cash flow, but one may have to accept higher rates of nitrogen losses. When Returns to Labour is the primary criterion (as it can be in smallholder systems), oil palm + cocoa is equivalent with oil palm monoculture (lower risk, slightly lower average), but oil palm + pepper stays behind.
Where there are multiple opinions on the relative importance of these indicators, and different resource endowments, we can expect a mosaic landscape to emerge with diversity in farming styles. From an aggregate perspective such a mosaic may be more resilient and functional than a landscape where only a single land use system (be it monoculture or mixed system) exists.

Naylor et al. (2019) concluded that both environmental conditionality and positive financial incentives are needed within Indonesia's Village Law of 2014 to enhance rural development while minimizing environmental damages from current oil palm development based on monocultures. The modelling exercise presented here had to leave many options out of consideration, such as inclusion of semi-domesticated trees from the forest with high value such as eaglewood (gaharu). This value can only be captured when new products and markets are developed and when prices stay attractive even when "harvesting" a rare species from the forest is replaced by mainstream cultivation of larger volumes (Soeharto et al., 2016). Oil palm + livestock combinations have also not been included in our exercise as the WaNuLCAS model is not suitable to assess such systems. Yet they merit attention and assessment as smallholders and companies have been observed to practice livestock grazing in their oil palm plantations, but no studies have been published yet on their economic and environmental performance.

\section{CONCLUSIONS}

Based on our model exploration, mixed oil palm cultivation systems are expected to provide considerable economic and environmental system improvements. The performance varied over a set of economic and environmental indicators and weighing factors should be applied to choose the system that provides the desired balance between economic and environmental enhancement. The only indicator at which an oil palm monoculture showed to be superior to any diversification scenario was the high returns to labour as it required lower labour compared to mixed systems. Mixed systems can support oil palm as a biofuel crop by reducing its carbon footprint. From the perspective of the land sharing vs. land sparing debate, mixed oil palm can be a way to achieve land sparing through more efficient use of land.

\section{DATA AVAILABILITY STATEMENT}

The datasets generated for this study are available on request to the corresponding author.

\section{AUTHOR CONTRIBUTIONS}

This work was part of the Ph.D. thesis successfully defended at Wageningen University by $\mathrm{NK}$, with $\mathrm{MN}$ and $\mathrm{MSl}$ as copromotors, jointly with NK conceiving the study, and advising on the implementation. MSo contributed to the economic analysis. DS and AM contributed to the analysis as M.Sc students, jointly supervised by $\mathrm{NK}, \mathrm{MN}$, and $\mathrm{MSl}$. $\mathrm{KH}$ contributed part of the data used for model validation. 


\section{FUNDING}

This research was part of the Forests, Trees, and Agroforestry research program of the CGIAR, implemented at World Agroforestry.

\section{REFERENCES}

Adam, H., Collin, M., Richaud, F., Beulé, T., Cros, D., Omoré, A., et al. (2011). Environmental regulation of sex determination in oil palm: current knowledge and insights from other species. Ann. Bot. 108, 1529-1537. doi: 10.1093/aob/mcr151

Amoah, F. M., Nuertey, B. N., Baidoo-Addo, K., Oppong, F. K., Osei-Bonsu, K., and Asamoah, T. E. O. (1995). Underplanting oil palm with cocoa in Ghana. Agroforestry Syst. 30, 289-299. doi: 10.1007/BF00705215

Bayala, J., Heng, L. K., van Noordwijk, M., and Ouedraogo, S. J. (2008). Hydraulic redistribution study in two native tree species of agroforestry parklands of West African dry savanna. Acta Oecolo. 34, 370-378. doi: 10.1016/j.actao.2008.06.010

Breure, C.J. (1982). Factors affecting yield and growth of oil palm tenera in West New Britain. J. Oleagineux 37, 213-222. doi: 10.1007/bf00705215

Cadisch, G., de Willigen, P., Suprayogo, D., Mobbs, D. C., van Noordwijk, M., and Rowe, E. C. (2004). "Catching and competing for mobile nutrients in soils," in Belowground Interactions in Tropical Agroecosystems, eds M. van Noordwijk, G. Cadisch, and C. K. Ong (Wallingford: CAB International), 171-191.

Carlson, K. M., Curran, L. M., Ratnasari, D., Pittman, A. M., Soares-Filho, B. S., Asner, G. P., et al. (2012). Committed carbon emissions, deforestation, and community land conversion from oil palm plantation expansion in West Kalimantan, Indonesia. PNAS 109, 7559-7564. doi: 10.1073/pnas.1200452109

Corley, R. H. V., and Tinker, B. (2015). The Oil Palm, 5th Edn. Oxford: Blackwell Science.

Davis, S. C., Boddey, R. M., Alves, B. J. R., Cowie, A., Davies, C., George, B., et al. (2013). Management swing potential for bioenergy crops. Glob. Change Biol. Bioenergy 5, 623-638. doi: 10.1111/gcbb.12042

Directorate General of Estate Crops (2016a). Statistik Perkebunan Indonesia (Tree Crop Estate Statistics of Indonesia), 2015-2017, Kelapa Sawit (Oil Palm). Jakarta.

Directorate general of estate crops (2016b). Statistik Perkebunan Indonesia (Tree Crop Estate Statistics of Indonesia), 2015-2017, Cocoa. Jakarta.

Directorate general of estate crops (2016c). Statistik Perkebunan Indonesia (Tree Crop Estate Statistics of Indonesia), 2015-2017, Lada (Pepper). Jakarta.

Dupraz, C., Wolz, K. J., Lecomte, I., Talbot, G., Vincent, G., Mulia, R., et al. (2019). Hi-sAFe: a 3D agroforestry model for integrating dynamic tree-crop interactions. Sustainability 11:2293. doi: 10.3390/su11082293

Gawankar, M. S., Devmore, J. P., Jamadagni, B. M., Sagvekar, V. V., and Khan, H. H. (2003). Effect of water stress on growth and yield of Tenera oil palm. J. Appl. Hortic. 5, 39-40.

Gérard, A., Wollni, M., Hölscher, D., Irawan, B., Sundawati, L., Teuscher, M., et al. (2017). Oil-palm yields in diversified plantations: initial results from a biodiversity enrichment experiment in Sumatra, Indonesia. Agri. Ecosyst. Environ. 240, 253-260. doi: 10.1016/j.agee.2017.02.026

Hutabarat, S., Slingerland, M., Rietberg, P., and Dries, L. (2018). Costs and benefits of certification of independent oil palm smallholders in Indonesia. Int. Food Agribus. Man. Rev. 21, 681-700. doi: 10.22434/IFAMR2016.0162

Ickowitz, A., Rowland, D., Powell, B., Salim, M. A., and Sunderland, T. (2016). Forests, trees, and micronutrient-rich food consumption in Indonesia. PLoS ONE 11:e0154139. doi: 10.1371/journal.pone.0154139

Joshi, L., Wibawa, G., Beukema, H. J., Williams, S. E., and van Noordwijk, M. (2003). "Technological change and biodiversity in the rubber agroecosystem," in Tropical Agroecosystems: New Directions for Research, ed J. Vandermeer ed (Boca Raton, FL: CRC Press), 133-157.

Khasanah, N. (2019). Oil palm (Elaeis Guineensis) production in Indonesia: carbon footprint and diversification options (Ph.D. thesis). Wageningen University, Wageningen, Netherlands.

Khasanah, N., Perdana, A., Rahmanullah, A., Manurung, G., Roshetko, J., van Noordwijk, M. (2015a). Intercropping teak (Tectona grandis) and maize (Zea mays): bioeconomic trade-off analysis of agroforestry management practices in Gunungkidul, West Java. Agroforestry Sys. 89, 1019-1033. doi: $10.1007 /$ s10457-015-9832-8

\section{ACKNOWLEDGMENTS}

Discussions with and comments from practitioners in oil palm production helped shape this research. We acknowledge comments from two reviewers.

Khasanah, N., and van Noordwijk, M. (2018). Subsidence and carbon dioxide emissions in a smallholder peatland mosaic in Sumatra, Indonesia. Mitig. Adap. Strateg. Glob. Chang. 24, 147-163. doi: 10.1007/s11027-018-9803-2

Khasanah, N., van Noordwijk, M., and Ningsih, H. (2015b). Aboveground carbon stocks in oil palm plantations and the threshold for carbon-neutral vegetation conversion on mineral soils. Cogent Environm. Sci. 1:1119964. doi: 10.1080/23311843.2015.1119964

Khasanah, N., van Noordwijk, M., Ningsih, H., and Rahayu, S. (2015c). Carbon neutral? No change in mineral soil carbon stock under oil palm plantations derived from forest or non-forest in Indonesia. Agri. Ecosyst. Environ. 11, 195-206. doi: 10.1016/j.agee.2015.06.009

Koh, L. P., Miettinen, J., Liew, S. C., and Ghazoul, J. (2011). Remotely sensed evidence of tropical peatland conversion to oil palm. PNAS 108, 5127-5132. doi: $10.1073 /$ pnas. 1018776108

Koh, L. P., and Wilcove, D. S. (2008). Is oil palm agriculture really destroying tropical biodiversity? Conserv. Lett. 1, 60-64. doi: 10.1111/j.1755-263X.2008.00011.x

Loague, K., and Green, R. E. (1991). Statistical and graphical methods for evaluating solute transport models: overview and application. J. Contaminant. Hydrol. 7, 51-73. doi: 10.1016/0169-7722(91)90038-3

Manohara, D., and Wahyuno, D. (2013). Pedoman Budiday America. [Pepper Cultivation Guide]. Bogor: World Agroforestry Centre (ICRAF) Southeast Asia Regional Program.

Martin-Guay, M., Paquette, P., Dupras, J., and Rivest, D. (2018). The new Green Revolution: Sustainable intensification of agriculture by intercropping. Sci. Total Environ. 615, 767-772. doi: 10.1016/j.scitotenv.2017.10.024

Mertz, O., and Mertens, C. F. (2017). Land sparing and land sharing policies in developing countries - drivers and linkages to scientific debates. World Dev. 98, 523-535. doi: 10.1016/j.worlddev.2017.05.002

Migeon, A. F. (2018). Assessing the possibilities of intercropping oil palm and pepper, under the double-row avenue system (M.Sc thesis). Wageningen University, Wageningen, Netherlands.

Minang, P. A., van Noordwijk, M., and Duguma, L. A. (2019). "Policies for ecosystem services enhancement," in Sustainable Development Through Trees on Farms: Agroforestry in Its Fifth Decade, ed M. van Noordwijk (Bogor: World Agroforestry (ICRAF)), 311-323.

Mutert, E. (1999). Suitability of soils for oil palm in Southeast Asia. Better Crops Int. 13, 36-38.

Naylor, R. L., Higgins, M. M., Edwards, R. B., and Falcon, W. P. (2019). Decentralization and the environment: assessing smallholder oil palm development in Indonesia. Ambio 48, 1195-1208. doi: 10.1007/s13280-018-1135-7

Naylor, R. L., Liska, A. J., Burke, M. B., Falcon, W. P., Gaskell, J. C., Rozelle, S. D., et al. (2007). The ripple effect: Biofuels, food security, and the environment. Environ. Sci. Policy Sustain. Dev. 49, 30-43. doi: 10.3200/ENVT.49.9.30-43

Nchanji, Y. K., Nkongho, R. N., Mala, W. A., and Levang, L. (2016). Efficacy of oil palm intercropping by smallholders. Case study in South-West Cameroon. Agroforestry Syst. 90, 509-519. doi: 10.1007/s10457-015-9873-z

Okyere, S. A., Danso, F., Larbi, E., and Danso, I. (2014). Residual effect of intercropping on the yield and productivity of oil palm. Int. J. Plant Soil Sci. 3, 854-862. doi: 10.9734/IJPSS/2014/9038

Orewa, S. I. (2008). Designing agricultural development projects for the small-scale farmers: some lessons from the world bank assistance small holder oil palm development scheme in Nigeria. J. Appl. Sci. 8, 295-301. doi: 10.3923/jas.2008.295.301

Padfield, R., Hansen, S., Davies, Z. G., Ehrensperger, A., Slade, E., Evers, S., et al. (2019). Co-producing a research agenda for sustainable palm oil. Front. Forests Global Change 2:13. doi: 10.3389/ffgc.2019.00013

Pahan, I. (2015). Panduan Teknis Budidaya Kelapa Sawit. Jakarta: Penebar Swadaya. 
Phalan, B. T. (2018). What have we learned from the land sparing-sharing model? Sustainability 10:1760. doi: 10.3390/su10061760

Putra, E. T. S., Simatupang, A. F., Supriyanta, W., and, S., Indradewa, D. (2012). The growth of one-year-old oil palms intercropped with soybean and groundnut. J. Agric. Sci. 4, 169-180. doi: 10.5539/jas.v4n5p169

Renwick, A., and Schellhorn, N. (2016). "A perspective on land sparing versus land sharing," in Learning From Agri-Environment Schemes in Australia, eds D. Ansel, F. Gibson, and D. Salt (Canberra, ACT: ANU Press). doi: 10.22459/LFAESA.05.2016.09

Rowe, E. C., Hairiah, K., Giller, K. E., van Noordwijk, M., and Cadisch, G. (1999). Testing the safety-net role of hedgerow tree roots by $15 \mathrm{~N}$ placement at depths. Agroforestry Syst. 43, 81-93. doi: 10.1007/978-94-017-0679-7_5

Salako, F. K., Lal, R., and Swift, M. J. (1995). Intercropping oil palm (elaeis guineensis) with cocoyam (xanthosoma sagittifolium) on windrows and non-windrows in southern Nigeria. J. Sust. Agricul. 6, 47-60. doi: 10.1300/J064v06n01_05

Salim, A., Wijanarko, R. D. T., and Sutisna, E. (2009). Petunjuk Teknis Budidaya Dan Pasca Panen Kakao. Kendari: Balai Pengkajian Teknologi Pertanian Sulawesi Tenggara.

Schwarze, S., Euler, M., Gatto, M., Hein, J., Hettig, E., Holtkamp, A. M., et al. (2015). Rubber vs. Oil Palm: An Analysis of Factors Influencing Smallholders' Crop Choice in Jambi, Indonesia, GOEDOC-Dokumentenund Publikationsserver der Georg-August-Universität Göttingen. Available onlione at: http://resolver.sub.uni-goettingen.de/purl/?webdoc-3954 (accessed December 24, 2019).

Sheil, D., Casson, A., Meijaard, E., van Noordwijk, M., Gaskell, J., SunderlandGroves, J., et al. (2009). The Impacts and Opportunities of Oil Palm in Southeast Asia: What Do We Know and What Do We Need to Know? Bogor: CIFOR.

Simeh, A., and Ahmad,T. M. A. T. (2001). "The case study on the Malaysian palm oil," in Regional Workshop on Commodity Export Diversification and Poverty Reduction in South and South-East Asia, Bangkok, 3-5. Available online at: http://www.unctad.org/infocomm/diversification/bangkok/palmoil. pdf (accessed December 24, 2019).

Slingerland, M., Khasanah, N., van Noordwijk, M., Susanti, A., and Meilantina, M. (2019). "Improving smallholder inclusivity through integration of oil palm with crops," in Chapter 5.2 in Jezeer, Rosalien and Nick Pasiecznik, eds Exploring inclusive palm oil production (Wageningen: ETFRN and Tropenbos International), 147-154.

Soeharto, B., Budidarsono, S., and van Noordwijk, M. (2016). Gaharu (eaglewood) domestication: biotechnology, markets and agroforestry options. Working Paper No. 247. World Agroforestry Centre (ICRAF) Southeast Asia Regional Program, Bogor, Indonesia.

Stomph, D. (2017). Smallholder oil palm: space for diversification? (M.Sc thesis). Wageningen University, Wageningen, Netherlands.

Suboh, I., Norkaspi, K., and Zulfkifli, R. O. (2009). Double-Row Avenue System for Crop Integration With Oil Palm. Bandar Baru Bangi: MPOB Information Series No 465 .

Suprayogo, D., van Noordwijk, M., Hairiah, K., and Cadisch, G. (2002). The inherent 'safety-net' of an Acrisol: measuring and modelling retarded leaching of mineral nitrogen. Eur. J. Soil Sci. 53, 185-194. doi: 10.1046/j.1365-2389.2002.00447.x

Szumigalski, A. R., and van Acker, R. C. (2008). Land equivalent ratios, light interception, and water use in annual intercrops in the presence or absence of in-crop herbicides. Agron. J. 100, 1145-1154. doi: 10.2134/agronj2006.0343

Tata, H. L., van Noordwijk, M., and Werger, M. J. A. (2008). Trees and regeneration in rubber agroforests and other forest-derived vegetation in Jambi (Sumatra, Indonesia). J. Forest. Res. 5, 1-20. doi: 10.20886/ijfr.2008.5.1.1-20

Tscharntke, T., Clough, Y., Wanger, T. C., Jackson, L., Motzke, I., Perfecto, I., et al. (2012). Global food security, biodiversity conservation and the future of agricultural intensification. Biol. Conser. 151, 53-59. doi: $10.1016 /$ j.biocon.2012.01.068

van Noordwijk, M., Bargues-Tobella, A., Muthuri, C. W., Gebrekirstos, A., Maimbo, M., Leimona, B., et al. (2019c). "Agroforestry as part of naturebased water management," in Sustainable Development Through Trees on Farms: Agroforestry in its Fifth Decade, ed M. van Noordwijk (Bogor: World Agroforestry (ICRAF)), 261-287.

van Noordwijk, M., and Coe, R. (2019). "Methods in agroforestry research across its three paradigms," in Sustainable Development Through Trees on
Farms: Agroforestry in its Fifth Decade, ed M. van Noordwijk (Bogor: World Agroforestry (ICRAF)), 325-346.

van Noordwijk, M., Duguma, L. A., Dewi, S., Leimona, B., Catacutan, D., Lusiana, B., et al. (2018). SDG synergy between agriculture and forestry in the food, energy, water and income nexus: reinventing agroforestry? Curr. Opin. Environ. Sust. 34, 33-42. doi: 10.1016/j.cosust.2018.09.003

van Noordwijk, M., Khasanah, N., and Dewi, S. (2013). "Biofuel Emission Reduction Estimator Scheme (BERES): land use history, production system and technical emission factor," in Negotiation-Support Toolkit for Learning Landscape, eds M. van Noordwijk, B. Lusiana, B. Leimona, S. Dewi, D. Wulandarib (Bogor: World Agroforestry Centre (ICRAF) Southeast Asia Regional Programme), 198-102.

van Noordwijk, M., Khasanah, N., and Dewi, S. (2017b). Can intensification reduce emission intensity of biofuel through optimized fertilizer use? Theory and the case of oil palm in Indonesia. Global Change Biol. Bioenergy 9, 940-952. doi: $10.1111 / \mathrm{gcbb} .12398$

van Noordwijk, M., Khasanah, N., Garrity, D. P., Njenga, M., Tjeuw, J., Widayati, A., et al. (2019b). "Agroforestry's role in an energy transformation that reverses climate change," in Sustainable Development Through Trees on Farms: Agroforestry in its Fifth Decade, ed M. van Noordwijk (Bogor: World Agroforestry (ICRAF)), 241-260

van Noordwijk, M., and Lusiana, B. (1999). WaNuLCAS a model of water, nutrient and light capture in agroforestry systems. Agrofor. Syst. 43, 217-242. doi: 10.1007/978-94-017-0679-7_14

van Noordwijk, M., Lusiana, B., Khasanah, N., and Mulia, R. (2011). WaNuLCAS version 4.0, Background on a Model of Water Nutrient and Light Capture in Agroforestry Systems. Bogor: World Agroforestry Centre (ICRAF).

van Noordwijk, M., Pacheco, P., Slingerland, M., Dewi, S., and Khasanah, N. (2017a). Palm oil expansion in tropical forest margins or sustainability of production? Focal issues of regulations and private standards. Working paper 274. Bogor: World Agroforestry Centre (ICRAF) Southeast Asia Regional Program.

van Noordwijk, M., Zomer, R. J., Xu, J., Bayala, J., Dewi, S., Miccolis, A., et al. (2019a). "Agroforestry options, issues and progress in regional contexts," in Sustainable Development Through Trees on Farms: Agroforestry in Its Fifth Decade, ed M. van Noordwijk (Bogor: World Agroforestry, (ICRAF)), 97-120.

Vermeulen, S., and Goad, N. (2006). Towards Better Practice in Smallholder Palm Oil Production. Natural Resource Issues Series No. 5. London: International Institute for Environment and Development.

Villamor, G. B., Pontius, R. G., and van Noordwijk, M. (2014). Agroforest's growing role in reducing carbon losses from Jambi (Sumatra), Indonesia. Reg. Environ. Change 14, 825-834. doi: 10.1007/s10113-013-0525-4

Woittiez, L. S., van Wijk, M. T., Slingerland, M., van Noordwijk, M., and Giller, K. E. (2017). Yield gaps in oil palm: a quantitative review of contributing factors. Eur. J Agronomy 83, 57-77. doi: 10.1016/j.eja.2016.11.002

Wösten, J. H. M., Finke, P. A., and Jansen, M. J. W. (1995). Comparison of class and continuous pedotransfer functions to generate soil hydraulic characteristics. Geoderma 66, 227-237. doi: 10.1016/0016-7061(94)00079-P

Yu, Y., Stomph, T. J., Makowski, D., and van Der Werf, W. (2015). Temporal niche differentiation increases the land equivalent ratio of annual intercrops: a meta-analysis. Field Crops Res. 184, 133-144. doi: 10.1016/j.fcr.2015. 09.010

Zomer, R. J., Neufeldt, H., Xu, J., Ahrends, A., Bossio, D., Trabucco, A., et al. (2016). Global tree cover and biomass carbon on agricultural land: the contribution of agroforestry to global and national carbon budgets. Scient. Rep. 6:24020. doi: 10.1038/srep29987

Conflict of Interest: The authors declare that the research was conducted in the absence of any commercial or financial relationships that could be construed as a potential conflict of interest.

Copyright (c) 2020 Khasanah, van Noordwijk, Slingerland, Sofiyudin, Stomph, Migeon and Hairiah. This is an open-access article distributed under the term. of the Creative Commons Attribution License (CC BY). The use, distribution or reproduction in other forums is permitted, provided the original author $(s)$ and the copyright owner(s) are credited and that the original publication in this journal is cited, in accordance with accepted academic practice. No use, distribution or reproduction is permitted which does not comply with these terms. 